\title{
RECONFIGURING SCOTTISH POLITICS: DOMESTIC GOVERNANCE $v$ EUROPEAN INFLUENCE
}

\author{
Amanda Sloat, Institute of Governance, Public Policy and Social \\ Research, Queen's University Belfast
}

After winning a landslide victory in the 1997 general election, the new Labour government quickly made its mark on the political landscape of the United Kingdom (UK) by initiating a wide-ranging programme of constitutional reform. Under the leadership of Prime Minister Tony Blair the government reconfigured domestic politics by devolving power to the 'regions' (Scotland, Wales, Northern Ireland), restoring the London mayor, and reforming the House of Lords. This article focuses on the early days of the Scottish Parliament, which was established in November 1998, held its first elections on 6 May 1999, and was officially opened by the Queen on 1 July. The 129-member, unicameral legislature has authority over most domestic policies (e.g., education, health, local government), which are scrutinised by an effective system of cross-cutting committees. Although European affairs remain 'reserved' to Westminster, the Scottish Parliament is responsible for implementing European directives in devolved areas and over half its workload originates in the European Community (EC). Thus, Scotland must work within a system of multi-level governance as a large proportion of its legislative agenda is shaped in London and decided in Brussels.

As the parliament approaches its second elections in May 2003, political observers are beginning to evaluate how well the new legislature has performed during its first term. This article seeks to provide a comparative reference for such analyses by recalling what Scotland's political elites expected from the parliament during the six months preceding its establishment. It uses the conceptual framework of multi-level governance (MLG), which is loosely defined as negotiation among supranational, national, and sub-national governments "as the result of a broad process of institutional creation and decisional reallocation that has pulled some previously centralized functions of the state up to the supranational level and some down to the local/regional level." Most supporters of MLG $^{2}$ dispute the state-centric separation between domestic and international politics, believing instead that EC policy-making authority is shared among an

1 G Marks, 'Structural Policy and Multilevel Governance in the EC' in A Cafruny and G Rosenthal (eds), The State of the European Community: The Maastricht Debates and Beyond (1993) Vol 2, p 392.

2 See L Hooghe, 'Subnational Mobilisation in the European Union' (1995) 18(3) West European Politics 175; G Marks, L Hooghe and K Blank, 'European Integration from the 1980s: State-Centric v Multi-Level Governance' (1996) 34 Journal of Common Market Studies 341; S. Hix, 'The Study of the European Union II: The "New Governance" Agenda and Its Rival' (1998) 5(1) Journal of European Public Policy 38; and I Tömmel, 'Transformation of Governance: The European Commission's Strategy for Creating a "Europe of the Regions"' (1998) 8(2) Regional and Federal Studies 52. 
increasing number of participants ranging from governments to non-state actors.

This study seeks to better understand the meaning and operation of multilevel governance by examining its constituent parts. First, while predevolution Scotland was included in EC discussions as part of the UK, the study considers elite opinions about the extent to which Scottish politicians and officials participated in the creation of the UK negotiating line and ensured that Scottish interests were represented in Brussels by the UK government. Furthermore, it asks whether they expected the Scottish Parliament to make an identifiable difference by swaying policy outcomes through domestic and European channels. Second, while many elites believed the parliament would adopt a more holistic approach to policymaking by including civic interests, the study queries this perceived consensus about the meaning of governance under new constitutional arrangements.

The article begins by introducing the elites whose opinions were considered, namely, members of civic organisations, civil servants, and politicians. It develops a typology to assess elite views, using an actor-centred approach to multi-level governance. It then describes how elites expected the Scottish Parliament and Executive to affect EC policy-making at a domestic level, before turning to their views about Scotland's likely relationship with EC institutions. Next, the article explores elites' understanding of governance and suggests their domestic conception of this approach to policy-making has relevance at European level. The concluding section summarises the research findings and draws lessons for the future of Europe's youngest parliament.

\section{Actor Typology}

This analysis of expectations about Scotland's role in Europe draws from qualitative research. $^{3}$ It focuses on interviews with 60 'elites' conducted between November 1998 (following the publication of the Scotland Act to ensure equal knowledge about new structures) and May 1999 (preceding the first election to prevent partisan bias). Elites are understood here as influential, prominent, and well-informed "people in important or exposed positions." ${ }^{4}$ The sample of interviewees was carefully chosen to include all levels and aspects of government and society, ${ }^{5}$ enabling a comparison of opinions within and between groups. During interviews lasting between one and two hours, elites were asked the same series of open-ended questions designed to gauge their expectations and to identify key vocabulary. These 'privately stated' views were compared with opinions put forward in documents (e.g., civic publications, civil service working papers, party manifestos) and stated publicly at over 60 conferences and events.

${ }^{3}$ For more information about research methods and conclusions, see A Sloat, Scotland in Europe: A Study of Multi-Level Governance (2002).

4 L A Dexter, Elite and Specialized Interviewing (1970) p 5.

5 F Devine, 'Qualitative Analysis' D Marsh and G Stoker (eds) Theory and Methods in Political Science (1995) p 142. 
The study assesses what elites believe about Scotland's role in Europe, but also seeks to analyse why they hold certain views. It accepts that "we can make progress if we focus on policy actor behaviour - as well as on institutions and institutional relationships - in order to begin our search for a better understanding of the EU as a policy system or series of policy subsystems." It draws from the academic literature on New Institutionalism, ${ }^{7}$ which asserts that the behaviour of political elites is shaped by institutional norms. In other words, institutions "serve to structure the individual and collective choices faced by member governments, and thereby influence policy choices in ways that cannot be predicted from the preferences and relative power of the member states alone." It also uses the insights of Multi-Level Governance, which suggests that elite expectations are affected by the political level at which they work. For example, Hix draws on a rational choice approach that focuses "on the interests and strategies of actors in the EU policy process" and conceives of "individuals as utilitymaximizing and independent from social and political forces." 9 However, this article argues that these two approaches do not pay sufficient attention to actors' previous experiences - particularly their involvement in the devolution process.

To test this hypothesis the study builds on the actor-centred approach developed by Marks, which views "actors as agents of decision making in both international and domestic contexts." 10 Marks defines institutions as "sets of commonly accepted formal and informal norms that constrain political actors (individuals and groups of individuals) who are the only agents capable of goal-oriented action," 11 but he argues that actors may change them in favour of more appropriate ones. Thus, this study examines the correlation between actors' expectations and the norms of their institution, political level of employment, and individual experiences (including proximity to the devolution process). It develops a typology of actors who are involved in the legislative process, including members of Scottish civil society, officials, and politicians. Within each typology, opinions are assessed according to the political level - Edinburgh, London, Brussels - of an actor's employment. The typologies also include elites with varying degrees of involvement in the parliament's establishment, enabling consideration of how proximity to the devolution process affects the expectations of actors within and between categories. While this article will highlight areas of agreement between the typologies, it will also suggest that

6 J Richardson, 'Policy-Making in the EU: Interests, Ideas and Garbage Cans of Primeval Soups' J Richardson (ed), European Union: Power and Policy-Making (1996) p 20.

7 See S Bulmer, 'The Governance of the EU: A New Institutional Approach' (1994) 13 Journal of Public Policy 351; V Lowndes, 'Varieties of New Institutionalism: A Critical Appraisal' (1996) 74(2) Public Administration 181; K Armstrong and S Bulmer, The Governance of the Single European Market (1998).

8 M Pollack, 'The New Institutionalism and EC Governance: The Promise and Limits of Institutional Analysis' (1996) 9 Governance: An International Journal of Policy and Administration 429 at 430.

9 S. Hix, op cit $\mathrm{n} 2$ at 48.

10 G. Marks, 'An Actor Centred Approach to Multilevel Governance' C Jeffery (ed), The Regional Dimension of the European Union (1997) p 34.

11 Ibid $\mathrm{p} 22$. 
some differences may stem from varying involvement in the process of constitutional change. The remainder of this section will describe the three actor typologies, which are summarised below in Table 1.

The first category includes members of Scottish civil society, who can be viewed as the parliament's architects. Several campaigned for devolution, participated in the Constitutional Convention, and 'represented' civic Scotland in the absence of a legislature (e.g., Church of Scotland, Scottish Council of Voluntary Organisations, Scottish Trades Union Congress). Other key players include Scotland's European representatives in the Convention of Scottish Local Authorities (COSLA) and Scotland Europa. The collaborative efforts of many elites in the Constitutional Convention civic organisations, with Labour and Liberal Democrat politicians, lobbied for a parliament and proposed its design - and the Consultative Steering Group (CSG) - a civic and cross-party group that drafted standing orders for the new legislature - provided terms of reference for devolution discussions. Many of these proposals were incorporated into the parliament's final design. Their views are contrasted with those of civic members who were less involved in the parliament's establishment but remain affected by its operation (e.g., Scottish industries, umbrella business organisations, academics). Architects may have the hardest time post-devolution, as their designs may be altered and as the new legislature changes their role from 'spokespersons of' to 'contributors toward'.

Next, the builders represent officials in the Scottish Office and some Whitehall departments (the study examined the Cabinet and Foreign Offices). Their main task was to combine the architects' plans (CSG report) with government legislation (Scotland Act) to devise a devolution settlement that was an operational success and retained the unity of the UK. They focused on the promotion of the government line and the creation of an effective method of policy-making. Their work is recorded in the Memorandum of Understanding and concordats, which are non-legally binding agreements between the executives that cover aspects of policymaking (including European issues) and dispute resolution. Their role as political 'insiders' gave them more knowledge than other groups about the intricacies of devolution, while their neutrality as civil servants enabled them to assess the operation of pre-devolution procedures and make predictions about the anticipated strengths and weaknesses of the new settlement. Many of those who helped design the new structures are involved in the parliament's early operation, providing continuity while also retaining vital links between officials north and south of the border. This category also includes officials in EC institutions who articulated views about Europe's newest parliament; although they are removed from the process of its establishment, they work with its officials and provide a 'European' perspective.

Finally, the parliament's tenants are the first group of politicians to inhabit the structure constructed by the architects and builders. They brought their own expectations about their new home, particularly as some were involved with the Convention or inhabited houses of a different construction in Westminster or local government. This first group is determining working practices in the parliament, which may become institutional norms. The tenants' main tasks include representing their constituents and making policy for Scotland, which is being documented in legislation, speeches, and media 
reports. Candidates for the European Parliament and Westminster also fall within this category, as their respective levels of government interact with the Scottish Parliament. Their inclusion enables consideration of whether politicians in Scotland had different aspirations for the parliament than their counterparts in Strasbourg and London.

Table 1: Actor Typologies

\begin{tabular}{|llll|}
\hline & ARCHITECTS & BUILDERS & TENANTS \\
\hline Members & Civil society & Officials & Politicians \\
& & & \\
\hline Task & Devolution & $\begin{array}{l}\text { Operational } \\
\text { success }\end{array}$ & $\begin{array}{l}\text { Policy-making } \\
\text { Representation }\end{array}$ \\
\hline Record & Convention & Scotland Act & Legislation \\
& CSG & Concordats & Speeches \\
\hline Rurrent & Monitor & Policy Execution & Policy-Making \\
& Lobby & & Representation \\
\hline Future & Lose rep. role & Changeable & Changeable \\
& Evaluation & & \\
\hline
\end{tabular}

Table 1 synthesises the actor typologies. Because many elites in Scotland wear multiple hats, it is difficult to place them within a single category. For example, several Labour and Liberal Democrat politicians were members of the Constitutional Convention; thus, some architects became tenants while others now lack direct involvement. Relationships also developed predevolution between actors in various categories and have evolved during the parliament's early years. These blurred boundaries, which illustrate the importance of an actor-centred approach that considers the numerous factors shaping expectations, are represented in the table by an absence of vertical lines separating the categories.

\section{Scotland's Domestic Influence}

Research found that most elites in all categories believed Scotland's European involvement would have predominantly domestic effects. ${ }^{12}$ They did not expect the parliament or executive to exert significant influence on UK or EC policy outcomes, and some questioned whether domestic legislation would differ from that produced by the old Scottish Office. Instead, most focused on the potential for a more participative and transparent policy-making process. Despite general agreement among elites,

12 For a more detailed analysis see A Sloat, 'An Actor-Centred Approach to MultiLevel Governance: Expectations of Scotland's Role in Europe' (2002) 12(3) Regional and Federal Studies 156. 
their varying attitudes toward constitutional change between actor categories caused some divergent opinions of Scotland's European role. Other differences stemmed from their proximity to the devolution process, creating contrary views within categories and shared aspirations between them. This section compares their views of domestic channels of influence, while the following section will assess their expectations about European channels.

\section{Representation}

The study began by considering whether elites believed Scotland was adequately involved pre-devolution in the UK's formation of EC negotiating lines. Most elites in all categories said Scotland was represented as part of the UK as a whole, but they disputed the UK government's handling of 'distinct Scottish interests'. While it remains unclear whether this dispute stemmed from frustration with the policy stances of the Conservative government (1979-97) or a flaw in the mechanisms used to create the UK position, the former seems more likely given the satisfaction expressed by some (particularly non-political) actors. When elites were asked whether Scotland's policy objectives differ substantially from England's, they nearly unanimously cited policies that are devolved or of statistically disproportionate interest. In particular, they named agriculture, fishing, and structural funds. These areas do not differ from English priorities in substance, but Scotland places a certain emphasis on particular aspects due to its distinct history, geography, and institutions. While elites did not expect the Scottish Executive to promote a radically different stance on EC policies from England, they believed it could accommodate more subtle needs by implementing directives, lobbying Whitehall, and promoting views to other regions and Commission officials.

Evaluation of Scotland's pre-devolution involvement differed according to elites' proximity to the legislative process, as many cited the dominant role of the civil service and said the lack of transparency hindered accurate assessment. There was a correlation between actors' inside knowledge of the political process and their conclusions about its effectiveness. Most architects, some European builders, and tenants from 'opposition' parties had little personal experience of government procedures and believed Scotland was badly represented. In contrast, architects with European experience (representatives of Scottish industries, COSLA, Scotland Europa), UK builders, and tenants whose parties had recently served in government reported adequate Scottish involvement. When asked what difference the devolution settlement would make to Scotland's role in EC policy-making, most elites emphasised its handling of domestic affairs and ability to implement directives in devolved areas. Although the Scottish Office occasionally implemented differently from England in the past, UK builders thought this would increase post-devolution as the existence of a domestic legislature enables more time for thorough consideration. Architects expected the parliament to become a focus for interests, involving civic actors in pre-legislative scrutiny and consultation.

Despite hopes for a new style of policy-making, the majority of elites in all categories expected the internal machinery to remain the same as most negotiations between the Scottish and UK governments will continue through existing civil service channels. On one hand, devolution may change the legislative process in Scotland by making it more transparent and 
accountable; this reflects the expectation that the parliament will 'democratise the Scottish Office'. On the other hand, elites anticipated continuity through the work of a unified civil service; this raises questions about the effectiveness of the parliament's new operating practices and may lead to calls for civil service reform. Most elites expected devolution to make Scotland's views known more widely at home and abroad: in the UK, the parliament provides another tool for Scotland to lobby Westminster; in Europe, it confers democratic authority on the assertion of Scottish interests. Such visibility introduces greater accountability into the policy-making system, enabling the Scottish electorate and other European states to judge whether the UK government has incorporated Scottish views.

However, it is questionable whether Scotland will actually win more battles as transparency does not necessarily equal increased political persuasiveness. Elites who remained sceptical about the devolution settlement expressed concern about decreased representation. Conservative and SNP politicians predicted less interaction between Scottish and Whitehall departments, the loss of Cabinet links, and a weaker (or eventually no) Secretary of State. The latter were particularly worried that the devolution settlement is premised upon Labour administrations in London and Edinburgh, and questioned the ability of an SNP administration to participate actively in EC policy-making. Several architects predicted that officials could lose information through civil service channels, ministers may be marginalised as decisions are taken in London, tensions between the executives could hamper Scottish involvement, and formerly Scottish-run issues such as forestries will be handled by UK ministers. There were also fears that Scotland may become either too insular in an attempt to solve all problems itself or too independent by repeatedly bypassing Westminster.

Because most post-devolution discussions about EU policy continue to occur within the unified civil service or between ministers on a confidential basis as per the concordats, it remains difficult to evaluate the extent to which Scotland has gained additional political authority in making its case to the UK government. However, recent research suggests these elite expectations were fairly accurate. ${ }^{13}$ Some Scottish Executive officials question whether Whitehall treats Scotland any differently, suggesting the biggest change is more active civic involvement in the legislative process. The European Committee and Executive have been effective at scrutinising European proposals, involving civic organisations in the consultation process, and publicising issues under consideration. Politically active organisations have enjoyed accessible politicians and a legislature closer to home, but the parliament seems to have made little impact on individual citizens and disaffected groups. ${ }^{14}$ Perhaps most surprising is the limited use the Scottish Executive has made of its ability to implement EC directives differently from the rest of the UK, though its implementation of the Water Framework Directive through primary legislation is a notable exception.

13 A Sloat, 'Scotland and the European Union: A Contribution to EU Governance Debates' (2001) in Scottish Parliament European Committee, Report on the Governance of the European Union and the Future of Europe: What Role for Scotland? Ninth Report, Volume 1 - Main Report, 11 December.

14 See J Curtice, D McCrone, A Park and L Paterson, New Scotland, New Society? Are Social and Political Ties Fragmenting? (2002) 


\section{Channels of Influence}

Despite a mixed appraisal of the UK's past representation of Scottish interests in Europe, nearly all elites in the original study stressed the continued importance of domestic negotiations after the parliament's establishment. They cited officials as the most effective pre- and postdevolution channel for relaying Scottish views to Whitehall, as the UK civil service remains unified and ministers become involved only when problems arise. UK builders, who have the greatest knowledge of past and present procedures, did not expect devolution to affect Scotland's level of representation or input into UK deliberations; they said Scottish officials already participate in areas of interest and this process will simply be formalised. However, elites coupled their recognition of continuity with an emphasis on likely change. Unlike the internal handling of disputes during 'administrative devolution', many elites expected the parliament to publicise the existence of different opinions from England.

Elites also stressed the importance of co-operation between politicians on different political tiers. UK builders were the most effusive about such connections. Some architects and tenants (particularly MEP hopefuls) envisioned a greater role for MEPs, who can provide an early warning about forthcoming legislation, information about other states' position, and a Scottish voice in the European Parliament. These actors said MPs can focus on reserved matters, pressure the government, and ask parliamentary questions. Although uncertain about relations between the parliaments and their committees, they highlighted partisan links and personal connections (e.g., Scottish chairman of the Commons' European Committee).

While the parliament's first term saw no direct links and relatively little contact between the Scottish and UK European Committees, officials servicing the committees have developed liaison mechanisms. Politicians are co-operating through the EMILE forum (European Elected Members Information and Liaison Exchange), whose twice-yearly meetings are attended by the Europe minister, European Committee MSPs (Members of the Scottish Parliament), Scottish MEPs (Members of the European Parliament), and Scottish members of COR. In addition, the Memorandum of Understanding ${ }^{15}$ established the Joint Ministerial Committee (JMC) to enable senior officials and/or ministers from the relevant ministries of devolved administrations and Whitehall departments to discuss UK positions on European matters and to resolve disputes between administrations over devolved issues. The original study was unable to assess expectations about the JMC given little publicly available information, though there were documented concerns about its potential for UK interference. ${ }^{16}$ The effectiveness of the JMC as a decision-making forum seems limited, as it only met once in the parliament's first two years to discuss European matters.

15 Scottish Executive, Memorandum of Understanding and Supplementary Agreements between the United Kingdom Government, Scottish Ministers and the National Assembly for Wales (1999).

16 See, e.g., A Barnett, 'Corporate Control' (1999) Prospect, Feb, p 24. 
Although elites emphasised domestic co-operation, the original study questioned whether they expected the UK government to restrain Scotland's autonomy. When asked about the likelihood of parliamentary debates on reserved policies, the majority of elites said the new legislature would want to consider all relevant issues but warned about the need to prioritise devolved areas. Elites were more concerned about the concordats, as their ability to regulate certain channels of participation confirmed the belief of many that officials would control the legislative process. While some architects hoped these informal guidelines would guarantee increased Scottish participation, most tenants (except Conservatives) suspected they would restrict Scottish involvement. Although all UK builders said the concordats were not legally binding and could be amended, Whitehall officials repeated the need for a unified UK line while Scottish Office officials feared their southern colleagues would have difficulty surrendering their legislative dominance.

During their first term the Scottish Parliament and Executive have enjoyed significant autonomy, though they have not utilised this freedom to enact radical policy initiatives or deviate from the UK line when implementing EC directives. Despite initial fears about the concordats' ability to restrict Scottish activities, they are rarely used in practice and officials suggest they are only referred to as a last resort for clarification. While there is increasing awareness of ways in which Scotland could act differently on EU matters from the rest of the UK, Scottish officials cite a desire in some Whitehall departments to retain GB- or UK-wide implementation. ${ }^{17}$ Limited financial and staff resources have kept Scottish officials dependant on their Whitehall colleagues for scientific expertise and legal drafting. There are also battles to be fought with the Scottish Executive: many of their discussions with the UK government occur behind closed doors and hinder committee scrutiny, while efforts are made by Labour-dominated executives in Edinburgh and London to retain a unified UK position.

\section{Scotland's European Influence}

Having considered elite expectations about the domestic effectiveness of the Scottish Parliament and Executive, the study looked at Scotland's ability to 'bypass' Westminster by promoting its views directly in Brussels. Most elites agreed that Scotland could pursue autonomous action, but concluded that co-operation is more effective than opposition (especially as the UK may not support Scotland in the future). The views of certain actors reflected their attitudes toward the devolution settlement: some builders (Whitehall officials) and tenants (Conservative politicians) were fearful about the implications of autonomous Scottish action for the union, while architects with government experience said the bypass occurs already. Attitudes also differed within and between categories. Several tenants (SNP and Labour candidates) said the strategy should be used if the UK government fails to incorporate Scottish views on important policies, while other architects (COSLA officials) and builders (Scottish Office officials) said Scotland could highlight distinct needs that are supported but not prioritised by the UK.

17 A Sloat, op cit $\mathrm{n} 13$. 
The rest of this section focuses more specifically on elite expectations about Scottish involvement in EC institutions, including the Executive's European office, the Council of Ministers, the Commission, and the Committee of the Regions. Few elites expected these channels to enable the Scottish Executive to exert more influence on EC legislative outcomes than the Scottish Office did. But most believed devolution would alter the nature of Scottish participation: the parliament will create a higher profile for Scotland, while the executive can speak with democratic authority and build relations with other sub-national actors.

\section{Scottish Executive European Office}

The main 'non-institutionalised' channel used by sub-national authorities to promote views in Brussels is a regional information office. Before devolution Scotland was represented by Scotland Europa, a subsidiary of Scottish Enterprise and membership organisation that provided a Scottish presence in Brussels given the absence of parliamentary representation. Most elites praised the office for creating a profile, building networks, and providing a platform for lobbyists. They also supported the creation of the Scottish Executive's European Office, which is now co-located with Scotland Europa under the umbrella of Scotland House, to monitor EC policy developments and provide Scottish information to the Commission. Interviewees did not expect it to exert greater influence than Scotland Europa, but thought it would raise Scotland's profile, co-ordinate activity among political actors, and enable more active participation in networks of regions with similar legislative powers.

The study measured the potential autonomy of the Executive office by considering the prospect of conflict with the UK Permanent Representation (UKRep) to the EU. ${ }^{18}$ The majority of architects and tenants expected the offices to co-operate and have few problems. Those with proximity to the EC policy-making process (COSLA and Scotland Europa officials) were more hopeful, recalling healthy relations between UKRep and Scotland Europa and predicting that strain would only be part of a larger domestic dispute or driven by partisan differences. However, builders held divergent views. Scottish Office officials in Edinburgh predicted little conflict, citing the need for co-operation and expecting most disputes to be handled domestically. Their Brussels-based counterparts were more assertive, expressing a willingness to fight for Scottish interests while acknowledging the possibility of subsequent tension and domestic repercussions. In contrast, Foreign Office officials warned against independent action and voiced concern about the location of the Executive's office outwith UKRep.

Since opening in October 1999, the Scottish Executive European Office has hosted 6500 delegates (e.g. European Committee, COSLA delegation), arranged 36 ministerial visits (including 29 by Scottish ministers), and

18 For more information on the relationship between regional information offices and member states' permanent representations, see C Jeffery, 'Regional Information Offices in Brussels and Multi-Level Governance in the EU: A UK-German Comparison' C Jeffery (ed), The Regional Dimension of the European Union (1997) p 183. 
assisted 1100 other visitors on business. ${ }^{19}$ It held conferences on EC/EU policies relevant to Scotland, improved co-operation with other regions, monitored the EC legislative process, and reported developments to Scottish decision-makers. While its officials cite an increase in Scotland's European profile and good working relations in Brussels, it is unclear whether Scottish views are more influential post-devolution. There is little reported tension with UKRep, which may be attributable to the Executive's initial caution, the unified civil service, and Labour-led governments in Edinburgh and London.

\section{Council of Ministers}

Although the Council of Ministers is dominated by member states by design, documents produced during the 1990s by the Scottish Constitutional

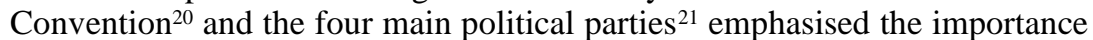
of Scottish participation in meetings. Most interviewees, however, admitted this would be limited and dependent upon good relations between the Executives. They hoped Scottish ministers would continue pre-devolution practices of attending Council meetings in areas of disproportionate interest, and expected them to speak occasionally on behalf of the UK and according to a pre-arranged stance.

Elites disagreed about the ability of Scottish ministers to lead a UK delegation. London-based officials were adamant that UK ministers alone will lead and decide whether to include their Scottish counterparts, while Scottish officials admitted that Scottish ministers were unlikely to lead but may in areas of exclusive competence. A few architects with little government knowledge, primarily businessmen, expected Scottish ministers to lead in areas of distinct interest; in contrast, a law professor said this was legally impossible. Tenants also held opposing views: SNP politicians said Scots could lead but questioned its occurrence, while Conservative politicians emphasised the domestic and European repercussions of such action.

Scottish participation in Council meetings has steadily increased during the parliament's first term, but remains a target of criticism by the SNP opposition. From July 1999 to mid-March 2001, Scottish ministers attended 18 meetings dealing with fisheries, agriculture, the environment, and education - all policies of disproportionate interest to Scotland. Scottish Executive officials attended 32 Council working groups from July to December 1999 and 67 during 2000, with a concentration on the same four

19 Scottish Executive European Office, 'Scotland House 1999-2000: One Year On' (2000), available at www.scotland.gov.uk/euoffice/shr2000.asp

20 Scottish Constitutional Convention, Towards Scotland's Parliament (1990); Scottish Constitutional Convention, Scotland's Parliament, Scotland's Right (1995).

21 See, for example, Scottish Conservative and Unionist Policy Commission, 'Scotland's Future' (1998); Scottish Labour Party, 'Scotland's Parliament: Labour Proposals for the Scottish Parliament' (1997); Scottish Liberal Democrat Party, 'Sovereignty and Integration: The Case for a Scottish Parliament' (1992); Scottish Liberal Democrat Party, 'Raising the Standard: Scottish Parliament Manifesto 1999' (1999); Scottish National Party, 'Rejoining the World: External Affairs and the Scottish Parliament' (1999). 
policy sectors. $^{22}$ During March 2001 to March 2002 officials attended 95 meetings, of which 26 involved civil law and 34 on fisheries. From March 2000 to December 2001 ministers attended 21 meetings $(12.8 \%$ of those held), primarily on the same subjects. ${ }^{23}$ In addition, the European Committee has sought to conduct greater pre- and post-Council scrutiny of the Executive's position; structures are now in place to enable the committee to receive timely information from the Executive, be better informed about the direction of EU policies, and pursue further intervention as required. ${ }^{24}$

\section{Commission}

Scottish documents and interviewees said relatively little in the original study about the Commission's utility to Scottish involvement in EC policymaking, though there was a link between elites' views and experiences of the institution. Many architects and tenants failed to recognise its potential: some businessmen and members of Scottish industries questioned whether the Commission would respond to one of many sub-national governments, while several politicians emphasised Scottish participation in the more visible but less easily influenced Council. In contrast, those architects (Scotland Europa, COSLA) and builders (EC officials) with Brussels experience cited its accessibility to sub-national authorities with special concerns. They also stressed the need for Scotland to replicate its strong domestic links in the European policy arena and develop a partnership approach across all levels of government.

Scottish officials had developed good links with their Commission counterparts pre-devolution, which have been advantageous during postdevolution discussions about potential problems with proposed directives. ${ }^{25}$ The Scottish European Committee welcomed the Commission's recent White Paper on European Governance, particularly its proposals to develop relations and consult more systematically with Europe's regions. The committee's own report on governance recognised the importance of timely Commission consultation:

"It is of critical importance that this is done at the prelegislative stage, in advance of the adoption by the College of Commissioners and is on a preferential basis for regions/nations with legislative power. From the point of

22 Answer by Jack McConnell MSP to questions raised in the Scottish Parliament on 29 March and 2 May 2001.

23 Answer by Jim Wallace MSP to questions raised in the Scottish Parliament on 25 February 2002.

24 Scottish Parliament European Committee, 'Briefing/Reporting by the Executive pre- and post-European Council and Council of the EU Meetings: an issues paper' (2002) EU/02/03/1, 5 Feb; Scottish Parliament European Committee, 'Briefing/Reporting by the Executive pre- and post-European Council, Council of the EU Meetings, Joint Ministerial Committees and MINICOR: proposed arrangements' (2002), EU/02/05/1, 20 March; Scottish Parliament European Committee 'Pre- and Post-European Council, Council of the EU, Joint Ministerial Committee and MINECOR Scrutiny' (2002), EU/02/09/8, 24 May.

25 A Sloat, op cit $\mathrm{n} 13$. 
adoption by the Commission, the debate in the EU is one of 'negotiation' and not one of 'formulation'."26

\section{Committee of the Regions}

The most accessible 'institutionalised' channel for sub-national authorities is the Committee of the Regions (COR), of which Scotland has four (of the UK's twenty-four) representatives and four alternates. Scotland's members were formerly local councillors, two of whom became MSPs and subsequent conveners of the European Committee. The concordats enable the Parliament to nominate members, who are currently split between the Parliament (1 full and 1 alternate member), Executive (1 full and 1 alternate), and local councillors ( 2 full and 2 alternates).

The majority of actors in all categories lacked knowledge about COR and assumed it was ineffective. They doubted its ability to enable Scottish politicians to sway policy discussions, criticised its limited authority and diverse membership, and faulted its tendency to express opinions on numerous subjects. However, architects (COSLA officials) and tenants (a former Labour member) with direct knowledge of the institution presented more favourable assessments, praising its representation of local government and regional interests. Continued frustration with COR's weaknesses has led constitutional regions to seek alternative channels of influence. ${ }^{27}$ For example, in May 2001 Scotland joined Catalonia and five other European regions (Salzburg, Rhineland-Westphalia, Bavaria, Wallonia, and Flanders) to sign the Political Declaration of the Constitutional Regions in the EU; it demanded a greater role for regions in the preparatory work for the 2004 Inter-Governmental Conference (IGC) and the future of the EU generally.

\section{Governance}

Because Scotland's political elites emphasised the Scottish Parliament's impact on domestic over European policy-making, it is worth examining how elites expected the devolved government to work differently from Westminster and to involve civic interests more effectively. ${ }^{28}$ Through frequent interaction during the 1990s, many elites developed shared ideas about governance based on the ideals of transparency and democratic accountability. For example, the CSG report established guiding principles of power-sharing, accessibility, responsiveness, and equal opportunities. ${ }^{29}$ Similarly, COSLA called for the parliament to "develop a distinctively Scottish approach to public policy by engaging in the policy process a wide range of stakeholders who are directly involved in the implementation of

26 Scottish Parliament European Committee, Report on the Governance of the European Union and the Future of Europe: What Role for Scotland? (2001) Ninth Report, Volume 1 - Main Report, 11 December.

27 E Roller and A Sloat, 'The Impact of Europeanisation on Regional Governance: A Study of Catalonia and Scotland' (2002) 17(2) Public Policy and Administration 68.

28 For a more detailed analysis of research findings see A Sloat, 'Governance: Contested Perceptions of Civic Participation' (2002) 39 Scottish Affairs 103.

29 Consultative Steering Group, Shaping Scotland's Parliament: Report of the Consultative Steering Group on Scotland's Parliament (1998). 
policy." ${ }^{30}$ While many elites think they share similar visions of policymaking, this section will explain how the various words they use to define 'governance' reflect divergent - and sometimes conflicting - views.

\section{Definition of Governance}

The study evaluated elite opinions about the European Committee to understand their definitions of governance. There was nearly unanimous support for the committee's CSG-proposed holistic structure, which is a potential tool for fostering new forms of governance, and for its efforts to 'mainstream' European affairs into the parliament's work. While most believed the committee would scrutinise and filter EC legislation, their emphasis on its additional tasks derived from their organisations' needs. Only architects expected the committee to play a significant role in implementation and, consequently, wanted to be involved in discussions about the most appropriate methods. Builders stressed the logistical process of handling legislation, citing the need to filter documents and liaise with officials and politicians at other government levels. Many tenants expected the European Committee to pass topical issues to other committees, while it could focus instead on macro issues.

At the beginning of the parliament's first term, the European Committee operated according to this CSG proposal by considering every EC/EU document at all stages of the legislative process, trying to prioritise them, and referring them - where necessary - to other committees. However, the committee found this system to be time-consuming and ineffective. It has since initiated new procedures whereby it classifies the list of documents received, distributes the list to other committees, and encourages them to inquire into relevant issues. The European Committee has refocused its efforts on scrutinising the Executive pre- and post-Council meetings.

There were similar divisions of opinion, which are summarised below in Table 2, when elites were asked about the involvement of non-MSPs on the European Committee as briefly considered by the CSG. The parliament's architects, some of whom participated in the Constitutional Convention and worked for organisations that 'spoke' for Scotland in the absence of a legislature, understood governance as civic participation in policy-making. While they all desired direct involvement with politicians, this defining process ranged from giving evidence (consultation) to joining parliamentary committees (direct participation). These preferences related primarily to the nature of their institution: members of civic organisations saw involvement as symbolic and desirable in itself; those affected by legislation, such as the COSLA and the National Farmers Union - Scotland, desired an inside voice in policy-making; and businessmen, whose industries were more affected by reserved areas, wished to be consulted but placed less emphasis on extensive involvement.

30 Convention of Scottish Local Authorities, 'COSLA, Local Government, and the Scottish Parliament: A Consultation Paper' (1998) p 1. 
Table 2: Understanding of Governance

\begin{tabular}{|llll|}
\hline & ARCHITECTS & BUILDERS & TENANTS \\
\hline $\begin{array}{l}\text { Defining } \\
\text { Principle }\end{array}$ & Participation & Co-Operation & Partnership \\
\hline Defining & Civic-Politician & Official-Official, & Politician-Civic \\
Relation & & Politician-Politician & \\
\hline $\begin{array}{l}\text { Defining } \\
\text { Process }\end{array}$ & Involvement & Liaison & Consultation \\
\hline
\end{tabular}

The other two categories articulated slightly different conceptions of governance. The parliament's builders were more concerned about Scotland's task of producing quality legislation within a UK structure than with incorporating civil society more closely into that process. Although officials supported a holistic approach to policy-making, many were cynical about the civic desire for a more participative democracy and questioned proposed consultation mechanisms. Their definition of governance focused on co-operation, especially among Scotland's three tiers of politicians and officials. They made few references to a legislative role for civil society, preferring that civic organisations promote rather than shape policies. Builders emphasised liaison as the defining process of interaction: they expected guidance from the concordats, cited goodwill between civil servants, and stressed the importance of information exchange among politicians.

Finally, the parliament's tenants used the rhetoric of governance most frequently. Focusing less on structures and links with other politicians, they articulated the civic desire for 'joined-up' government and collaboration with policy users. They defined governance as partnership, an understanding that was particularly evident in pre-election policy documents produced by all four parties ${ }^{31}$ and emphasised defining relations with 'the people' and civic organisations. Although tenants shared the architects' hope for greater interaction, they emphasised civic 'consultation' rather than more extensive 'involvement'. In particular, there was debate between parties with varying degrees of government experience: 'opposition' parties (SNP, Liberal Democrats) held 'people's assemblies' before the elections to ascertain the public view and their members tentatively supported including non-MSPs on committees, while candidates from parties with recent government experience (Labour, Conservatives) were more reluctant about radical mechanisms and cited their role as elected representatives.

31 Scottish Conservative and Unionist Policy Commission, op cit $\mathrm{n} 21$; Scottish New Labour Party, 'A Lifetime of Opportunity' (1998); Scottish New Labour Party, 'Building Scotland's Future' (1999); Scottish Liberal Democrat Party, 'How the Scottish Parliament Should Work: the Scottish Liberal Democrat Response to the Consultative Steering Group' (1998); Scottish Liberal Democrat Party, op cit n 21; Scottish National Party, 'Towards the Scottish Parliament: Policy Intentions for the 1999 Elections' (1998). 


\section{Analysis}

The most contentious issue in discussions about new forms of governance concerns the nature and extent of civic involvement. Expectations were the closest between architects and tenants, partially due to co-operation in the Constitutional Convention and CSG, some overlapping membership between categories, and a similar understanding of the electorate's needs. Builders' scepticism may present the most serious obstacle to reform, particularly as most elites expected officials to retain significant control over the internal policy-making process. However, the difficulty of reaching an acceptable compromise could be compounded by tension within - as well as between actor categories as architects and tenants disagreed amongst themselves about the desired role for civil society.

Another aspect of the 'Scottish' conception of governance is the prevalence of informal relations within a small elite. Close and frequent contact enabled the development of a common language, shared goals, and civic trust. It may also explain the consensus among actors about the parliament's likely operation and effect on policy-making. The House of Commons' Scottish Affairs Committee, which examined the implications of devolution, made a similar observation:

"The Scottish model offers an exciting opportunity to experiment with new methods of government and new and more equal relationships between government and the governed. ... Scotland has a major advantage in achieving this in that it is a relatively small country where the rest of the major players tend to know each other already so that the contacts have already been made." 32

Although established networks and shared experiences may help the creation of new forms of governance, the dominance of key individuals raises concerns about the potential exclusivity of Scotland's political elite. 'Outsiders' may struggle to find a niche, and there is a danger of (perhaps unintentional) clientelism as people utilise connections to obtain a political voice. The challenge in Scotland is devising a system that retains the benefits of close contacts while remaining open to interested - and previously uninvolved or excluded - participants.

Elites are increasingly cognizant about the importance of governance within the UK, as most supported interaction between Scottish politicians and officials at three tiers of government to exchange information and exert influence on multiple levels. They recognised the lack of co-operation in the past, calling for more cordial relations between MEPs and MSPs than had been experienced with MPs. They also acknowledged the dominant role of officials in pre-devolution negotiations between Scotland and the UK, and wanted to preserve good working relationships north and south of the border. Yet the 'Scottish' view of governance remains a primarily domestic concept that has yet to incorporate fully the European dimension. Although elites realised that overlapping policy competences must be shared by multiple

32 House of Commons Scottish Affairs Committee, The Operation of Multi-Layer Democracy (1998), Second Report, Volumes 1, 18 November, p ix. 
levels of government, some seemed uncertain how to operate on several tiers simultaneously and instead emphasised their primary tasks: those in Brussels said all regions face this overlap; Whitehall officials stressed the need to maintain a unified UK line; and Scottish-based interviewees highlighted the parliament's ability to implement legislation. Many also cited potential domestic problems, fearing that partisan conflict between Scottish and UK governments of differing political complexions could hinder participation and representation.

This discussion of conflicting understandings of governance has particular relevance following the publication of the European Commission's White Paper on European Governance. ${ }^{33}$ Scotland was an active participant in this debate, sharing many of its recent experiences. ${ }^{34}$ The preliminary working programme of the governance exercise reflects key principles identified by Scottish elites, defining governance as "rules, processes, and behaviour that affect the way in which powers are exercised at European level, particularly as regards accountability, clarity, transparency, coherence, efficiency and effectiveness." 35 The White Paper identified the need for greater civic and regional participation in policy-making, but was vague about detailed mechanisms. It emphasised consultation as a guiding principle, stating: "Participation is not about institutionalising protest. It is about more effective policy shaping based on early consultation and past experience. . . Better consultation complements, and does not replace, decision-making by the Institutions." "36 The challenge for both Scotland and the EU is, therefore, developing practical ways of implementing these generally supported concepts and clarifying the meaning of civic participation.

\section{CONCLUSIONS}

In conclusion, research found that most elites expected substantial continuity in Scottish policy-making post-devolution: the majority of civil service procedures stay in place, while many policy outcomes are likely to remain the same. But they expected a change in the legislative process according to new forms of governance, including more transparent and accountable policy-making, the visibility of distinct Scottish views that may contradict those of Westminster, and the creation of a democratic profile at home and abroad. In terms of Scotland's role in Europe, the majority of elites did not expect Scotland to exert greater influence on legislative outcomes. Rather, they highlighted the opportunity for more democratically legitimate and

33 European Commission, European Governance: A White Paper (2001), COM 428, 25 July.

34 The European Committee visited the Commission's Governance Team in March 2001, invited COR members to a wide-ranging debate about governance in May 2001, and held its own inquiry to examine how Scotland's new constitutional arrangements relate to EU issues. The Scottish Executive and COSLA submitted a 'Joint Discussion Paper on European Governance' to the Commission's inquiry, while Jack McConnell MSP (as Minister for Europe) addressed a hearing organised by the Commission's governance team in Brussels.

35 European Commission, 'White Paper on European Governance: Enhancing Democracy in the European Union, Work Programme, Commission Staff Working Document' (2000), SEC 1547/7, 11 October, p 4.

36 European Commission, op cit $\mathrm{n} 33$, pp 15-16. 
discernible participation. They expected the parliament to provide a focus for Scottish interests, while the executive can implement EC legislation in a suitable manner, lobby Westminster, and speak in Brussels with greater authority.

Although elites held many similar opinions about Scotland's European role, some disagreement between categories stemmed from divergent attitudes toward governance and devolution. Architects were the most enthused about 'new politics', but remained pragmatic about the opportunities for and limits of their new legislature. They emphasised the parliament's ability to foster new working practices over its ability to sway decisions in London or Brussels, stressing the involvement of civic organisations in creating and implementing legislation. Builders did not expect devolution to increase Scotland's participation in EC policy-making or affect legislative outcomes, but focused instead on co-operating to maintain efficient policy-making. They also highlighted the novel visibility of Scottish views within a unified UK system. Finally, tenants' expectations fell between those of the other actor typologies: some were involved with the Constitutional Convention and sympathised with the civic desire for greater involvement, while others emphasised their status as elected representatives and the need to preserve the union. In general, they highlighted the parliament's ability to focus attention on Scottish issues, consult civil society more extensively, and implement EC legislation in an appropriate manner.

There was a correlation between individuals' expectations and their proximity to the devolution process. Elites who were involved in the parliament's establishment - as campaigners, CSG members, MSP candidates, or Scottish officials - appeared more knowledgeable about its operation, optimistic about its ability to forge a new style of politics, and aware of the implications of devolution. Their views differed from those of actors who were further removed from the devolution process (UK and EU politicians, SNP and Conservative MSP candidates, some English and European officials, businessmen affected by reserved areas). Proximity to UK and EC policy-making also appeared to make some actors more hopeful about Scotland's ability to achieve satisfactory legislative outcomes; for example, UK builders were emphatic about Scotland's pre-devolution involvement in the UK's formulation of an EC negotiating line, while those with personal experience in Brussels were optimistic about Scotland's ability to make its voice heard. Policy-makers could apply the lessons of this actorcentred approach to the legislative process: as individuals with personal experience of an institution or process were more supportive than those who lacked first-hand knowledge, it would seem that actively including such actors should make them more supportive of the resulting legislation. In other words, policy-makers should adhere to civic calls for a shift from solely representative government to more participative governance.

There is evidence in Scotland that the government and civic organisations are beginning to develop new methods of governance, with committees taking the most active role in increasing legislative scrutiny and including civil society more directly in the policy process. The jury is still out in the case of Europe, as Scottish politicians and officials seek to increase their influence on EC policy-making while the European Commission struggles to determine the best mechanisms to encourage regional participation. The ongoing Convention on the Future of Europe, which was established by the 
Laeken European Summit in December 2001, is an attempt by the EU to involve civic organisations and politicians in discussions following the governance debate and preceding the 2004 IGC on pre-enlargement institutional reforms. While it is questionable whether this unwieldy forum will reach a meaningful consensus on issues such as the division of competences and treaty simplification, it is essential that politicians, civil servants, and members of civic organisations develop a meaningful dialogue that enables successful policy-making on multiple levels and the practice of good governance. 